\title{
Highland hill tribe language - An extinct language system needed to be saved
}

\author{
Tang Minh Chau ${ }^{1 *}$ \\ ${ }^{1}$ Ho Chi Minh City Open University, Vietnam \\ *Corresponding author: tangminhchautst@gmail.com
}

\begin{tabular}{|c|c|}
\hline ARTICLE INFO & ABSTRACT \\
\hline $\begin{array}{l}\text { DOI:10.46223/HCMCOUJS. } \\
\text { soci.en.8.1.275.2018 }\end{array}$ & $\begin{array}{l}\text { Highland is a typical area in Vietnam with a great deal of } \\
\text { unique things for people to study and discover. Among them } \\
\text { are culture and language, the two reciprocal elements to create }\end{array}$ \\
\hline Received: December $5^{\text {th }}, 2017$ & communities called Hill tribes. Original Hill tribes came to the \\
\hline Revised: March 6 $6^{\text {th }}, 2018$ & $\begin{array}{l}\text { Highland long time ago and set up their life based on their root } \\
\text { culture until now. When studying about Hill tribes, we realize }\end{array}$ \\
\hline Accepted: May $14^{\text {th }}, 2018$ & $\begin{array}{l}\text { that their culture is very interesting and worth tracing. } \\
\text { Therefore how to conserve Hill tribes' culture is what we need }\end{array}$ \\
\hline $\begin{array}{l}\text { Keywords: } \\
\text { bilingual, culture, highland, hill } \\
\text { tribes }\end{array}$ & to take into consideration as soon as possible. \\
\hline
\end{tabular}

\section{Introduction}

Every country in the world has their own culture and tradition. Throughout the change of time and events, they always try to maintain their culture as well as their language. Language is one of those we call tradition. Language is one of the effective ways which can sign their community and their special characteristic when distinguishing with others. We still survive with our people if we lose our territory or even the political system. However, if we lose our mother tongue, then our community will completely disappear. We have a lot of language types like first language, second language and even ethnic language. In the modern age with modern technology and development all over the world, we nearly lose our root language and are integrated by English and other international languages. Vietnam is a country of 54 ethnic groups with a lot of ethnic languages spoken by many minorities from the highlands or Mekong delta to the North. Although they can speak the Vietnamese language when converse with Kinh people but they still speak their mother tongue at home to maintain it. Among minority groups, the biggest community is of highland people which are also known as hill tribes. This paper attempts to discover highland people; their language, culture and how they maintain and promote their languages. Therefore, it will discover the policy to maintain and promote their language in a modern society with the assimilation of international and modern languages like English or other languages.

\section{Introducing ethnic minorities (hill tribes) and their language}

Vietnam is a country of 54 ethnic groups. Also, Vietnam has three geographical parts including the North, the Centrals and the South. The Highland is the Northwest part belonging to the South and partially the Central with a combination of 4 main plateaus: Daklak, Pleiku, Kontum and Lam Vien with erratic weather now hot during the day and now cold at night in the elevation of 500 - 900 meters. They are bounded by Laos and Cambodia on the left, the 
Central on the right and above and the South below. This is home to many ethnic groups called hill tribes because they live on the highland as communities. Among them are some biggest hill tribes with large communities living together in some villages near the city or even in the forest. They are Rahde, M'nong, Jarai and Banah. The Rahde inhabitants live close to Buon Ma Thuot city, a central city of the whole highland. Here, we can have an ethical tour with some of its villages and tourist places to see how their life is moving and motioning. The M'nong community lives about $45 \mathrm{~km}$ from Buon Ma Thuot city with their villages next to the "Lak" lake of Lak town. The Jarai group lives in Pleiku city, $190 \mathrm{~km}$ from Buon Me Thuot city. They are the most ancient hill tribes who lived here for a long. Their name was after the province "Gia Rai". The Banah lives close to KonTum province, the North point province of the Highland. The Banah is one of the originals and still preserve the root languages and cultures among the four hill tribe groups because they live near the forest. In fact, Kontum is not a developing province and everything still remains old and natural. It is obvious everything will change and be assimilated by the touch of technology and modern life.

\section{Origin}

It is not easy to trace the Hill tribe origin because they had settled in the Highland long before the time of feudalism in Vietnam. According to Gerald (1964), the Hill Tribe in highland originally came from some islands of Malaysia and Indonesia called Java. They came through Cambodia and then to Laos to seek a better life from way back. After a long time living there, they decided to pass the border to the Highland of Vietnam for some reasons: (1) They could exploit plentiful forest products here for a better living; and (2) they could get married to Vietnamese to create a harmonious community. This explained why we have a group of Hill Tribe called "M'nong - Lao", a combination of M'nong people and Laotian people. Those people live both in Laos and the Highland of Vietnam now. It is not strange why we can see current houses of Hill Tribes with the structure of a boat on their roof. That is a kind of worship to their ancestors, which were originally from Java islands coming here from boats on the sea.

\section{Culture and language}

Culture derives from geographical location. Therefore, what Hill tribe people embrace in their culture and how they think about social issues heavily depend on their place of living and the people they live with. The highlanders live most in the highland with an elevation of about 600 meters to 900 meters. The weather is hot in the afternoon and cold at night. The Highland has forests and plateaus with various kinds of products. So, human life is dangerous because of wild animals and creativity because of the various products they produce and consume. In brief, they have a culture of high solidarity that honors the values of hard-working and honest. They live as a community and stay in a village. As many tribes live in the same forest, they set up their own territory and made efforts to protect their village's uniqueness. This helped to create a community culture in the Hill tribe. The strict weather helped them to train themselves to overcome hardship and to survive. Also, the strict rules of the tribe taught them good lessons about honesty. For example, severe punishments would be applied for those who were found thieving. Every village has a leader called "headman", who is a judge in some prosecutions and decides the punishment. He is also the one who interacts with outer villages and handles affairs with the local authority. Particularly, in families of some groups like Ede, Mnong and Bahnar, the family head is usually not a man but a mother or a woman. This system is known as "Matrilineal kinship system". These women are mainly responsible for all family's affairs like earning money and taking care of children. 
About their living, villages often locate near a river or a lake because people believe in the power of water to can give them life and revive their existence in this world. They also live in stilt houses to avoid being attacked by wild animals. In their house, they set up a "Montaigne pig" cage to make it easy for pigs to look for food from the soil. The pigs then become an important source of food to treat the whole village in some big ceremonies. Most of the tribe houses have a fireplace to keep the home warm in such wild weather as in the Highland. Ede groups often live in a long stilt house called "Nha Dai" with three or four separate rooms for many generations of a family. When their son or daughter get married, they will lengthen the house by building a new part connected to it for the newly-wed couple to live with them. When the house cannot be lengthened, the couples will live next to the extended family in a small stilt house and continue the tradition when, in turn, their children get married. Especially, Bahnar groups have a very big "Nha Rong", a community house where all ceremonies or events are held. It can also be used as a court to adjudicate legal disputes. This house manifests their high focus on community culture. As Doanh (2007) stated, on big occasions or ceremonies like "Bo -thy" funeral, hill tribes will prepare a big buffalo and lots of "Can" wine to serve the whole village overnight. "Nha Rong" is also where they show their own achievements and exhibition of the community. Their achievement includes what they obtain after catching elephants or other products like Elephant tusk, Buffalo leather, or long chairs called "K'ban" made by "Pomu", a kind of precious wood.

About languages, it has been found that "Mon-Khmer" and "Austronesian" are two main language systems of Vietnam ethnic minorities. "Mon-Khmer" was spoken by Bahnar, M'nong and some other Hill tribes. This group of languages is a combination of "Khmer" from Cambodia language and "Mon" from Burma language. Some of those peoples came to Vietnam for a long and settled down here to create that language system. At this point, it can be inferred that "Bahnar" and Cambodian have a close relationship in terms of language and society as they were of the same root. If you make a trip to Cambodia, along the way you will easily find some houses made by wood with "stilt" style like houses of "Bahnar" people in Vietnam highland. The second language system is "Austronesian", a kind of language group originated from the Java islands of ancient Indonesia and Malaysia. They immigrated here and create a community in Vietnam. This language is spoken by "Ede", "J'rai" and some other Hill tribes.

\section{Current status and some plans for Hill tribe languages}

Honestly, I believe the language and even culture of Hill tribes are in danger now. Duc (n.d.) stated that "Due to the differences in the standards of development of the nationalities, the social functions of the languages in Vietnam vary to a large extent. Aside from some languages now in development, some others are in danger of extinction". This comment was just partially correct because I have made several visits to the Highland by myself and I found that the people there have rapidly switched from their traditional culture to modern culture to meet tourists' requirements. Particularly, people in Sapa, a famous mountainous tourist attraction in the north, had a unique cultural aspect called "love market" where Hill tribe people come every Saturday to look for a friend or intimate to hang out with. But things have totally changed today. The performers now tend to use Vietnamese instead of their own language and make "love market" a show for tourist and financial purposes. Such facts show increasing assimilation of ethnic culture and language into Vietnamese modern society. The quick change of society nowadays has made some ethnic traditions fade out. Accordingly, ethnic people have to update themselves with modern technology and information, and thus studying Vietnamese 
becomes a must. They have to use Vietnamese to acquire all information and then learn the language naturally. Accordingly, they sometimes have to use Vietnamese if they want their messages get through to their friends, thus their language becomes faded out gradually. In addition, the increasing marriages between ethnic and Kinh youngsters also put their language at risk. Children from these blended families learn in Vietnamese-speaking schools and seldom speak their mother tongue at home with their parents. Their mindset is different from that of the old. They are more interested in new and modern things to be cool with their peers, and do not pay much attention to keeping the long traditional values of their own language and culture. What Duc (n.d.) stated is partially correct, especially for some prosperous groups like M'nong, E'de, Cham (in the Central) and Kh'mer (Ancient Cambodian). With a big population, they can have enough human resources to maintain their own culture and tradition. Furthermore, they have shown that their culture is unique and have it popularized on many Vietnam's media like $\mathrm{TV}$, radio and so on. For other groups, it is hard to find their culture, tradition or language shown on means of media because their conservative customs do not allow the advertisement of these values. Finally, some old customs also restraint them from integrating into Vietnamese and introducing to the outer world their language and practices. They are still afraid of being cheated by strangers who are not their villagers.

For policies and efforts, Eric (2006) stated "The increasing mobility of people, goods, and information has driven a powerful trend toward cultural uniformity and the extinction of local languages. But languages that have young people, business, and government on their side are alive and thriving". As a Vietnamese with great concern about ethnic issues, I think it is necessary to have more bilingual schools for children of all Vietnam's ethnic groups to study because at least they should know how to read and write the Vietnamese language. Bilingual schools also help them to recall what they have heard from their parents at home every day. At these schools, they can both study Vietnamese and their mother tongue. One big challenge is that some mountainous provinces do not have teachers speaking ethnic languages to teach pupils at local schools. However. I personally think we can deal with this challenge because there are just 7 basic language systems including Mon-Khmer, Austronesian, Tay-Thai, VietMuong, etc. out of various ethnic languages. Based on this, we can assign a group of teachers who can speak those languages and fulfill at schools for each type of language. Besides, there should be more ethnic-language speaking channels at the proper time on local radio stations so that their voice can be heard and enable them to better understand all local and international issues. Finally, as suggested by Eric (2006), we can popularize and benefit by having ethical authors write about ethnic language and culture and having their books published officially. This way, we can both benefit ethnic authors and help readers easily approach ethnic-related issues.

In brief, more research needs to be conducted to investigate complicated issues relating to ethnic groups. Their language and culture are needed to preserve in a strict and serious way. Such issues need great concern from the government and related ministries and agencies. Various types of communication should be employed to fulfill the popularity of Hill tribe groups and to save their languages. Most importantly, the government should pay more attention to the influence and contribution of ethnic groups and their culture and language to the cultural richness of the country, and thus makes greater efforts to preserve and develop traditional values of all ethnic minorities. 


\section{References}

Doanh, N. V. (2007). Cai chet duoc hoi sinh [Death is revived]. Cleveland, NY: World Publishing House.

Duc, V. (n.d.). Status and state policies for ethnic groups and languages in adult education in Vietnam. Retrieved October 20, 2017 from http://www.eaea.org/index.php?k=12065

Eric, G. (2006). Can minority languages be saved? Globalization vs. culture. Retrieved October 20,2017, from https://omniglot.com/language/articles/minority_languages.php

Gerald, C. (1964). The major ethnic groups of the South Vietnamese. Retrieved October 25, 2017, from http://www.usq.edu.au/library/referencing/apa-referencingguide\#Proceedings_and_technical_reports

United Nations High Commissioner for Refugees, Status Determination and Protection Information Section (DIPS). (2006). Vietnam: Situation of indigenous minority groups in the central highlands. Retrieved October 26, 2017, from http://www.unhcr.org/refworld/pdfid/44c0f55a4.pdf

United States Agency International Development. (2008). Vietnam central highlands needs $\begin{array}{llll}\text { assessment. } & \text { Retrieved } & \text { October } & \text { 2017, from }\end{array}$ http://www.oecd.org/countries/vietnam/42305730.pdf 